\title{
Pengembangan Kompetensi Siswa Melalui Ekstrakurikuler Elektronika di SD FX. Marsudirini 78 Salatiga
}

\author{
Development of Student Competency Through Electronics Extracurricular at SD FX. \\ Marsudirini 78 Salatiga
}

\author{
Gunawan Dewantoro ${ }^{1 *}$, Raynald Saputra ${ }^{1}$, Yohanes Dino Lowutan ${ }^{1}$, Deddy Susilo ${ }^{1}$ \\ ${ }^{1}$ Program Studi Teknik Elektro, Universitas Kristen Satya Wacana, Salatiga \\ *gunawan.dewantoro@uksw.edu
}

\begin{abstract}
ABSTRAK
Pelajaran ekstrakurikuler merupakan aktivitas di luar jam pelajaran yang memiliki tujuan untuk melengkapi kompetensi siswa dalam berbagai bidang salah satu contohnya adalah di bidang elektronika yang dilaksanakan di SD FX. Marsudirini 78 Salatiga. Kegiatan pengabdian ini dilatarbelakangi oleh adanya keinginan pihak sekolah untuk mendorong kemampuan siswa dalam berpikir kreatif serta diharapkan mampu mempersiapkan siswa di tengah perkembangan teknologi yang sangat pesat. Karena belum adanya pengalaman untuk menyelenggarakan ekstrakurikuler elektronika, maka kegiatan pengabdian masyarakat ini bertujuan untuk mempersiapkan pihak sekolah secara mandiri menyelenggarakan kegiatan serupa di masa mendatang. Metode yang dilakukan adalah dengan mempersiapkan materi ajar, peralatan, bahan habis pakai, serta melaksanakan pelajaran ekstrakurikuler baik teori maupun praktek selama satu tahun. Hasil yang didapatkan dari kegiatan ini adalah meningkatnya wawasan dan ketrampilan siswa ajar sekaligus memberikan bekal awal bagi pihak sekolah untuk melaksanakan ekstra kurikuler elektronika secara mandiri.
\end{abstract}

Kata kunci - Ekstrakurikuler, pembelajaran, elektronika

\begin{abstract}
Extracurricular lessons are activities outside of class hours that have the aim of complementing student competencies in various fields, one example of which is in the field of electronics which is held at SD FX. Marsudirini 78 Salatiga. This service activity is motivated by the desire of the school to encourage students' ability to think creatively and is expected to be able to prepare students in the midst of very rapid technological developments. Because there is no experience to organize electronic extracurricular activities, this community service activity aims to prepare the school to independently organize similar activities in the future. The method used is to prepare teaching materials, equipment, consumables, and carry out extracurricular lessons both theory and practice for one year. The results obtained from this activity are increasing the insight and skills of teaching students as well as providing initial provisions for the school to carry out extra-curricular electronics independently.
\end{abstract}

Keywords - Extracurricular, learning, electronica 


\section{Pendahuluan}

Melalui pendidikan formal, diharapkan siswa-siswi dapat mengoptimalkan segala bakat dan minat masing-masing sehingga dapat bermanfaat bagi kebutuhan pribadinya maupun masyarakat. Kegiatan ekstrakurikuler, sebagai tambahan dari pendidikan formal, bertujuan untuk merangsang kreativitas, menambah wawasan, melatih tanggung jawab. Selain itu dapat siswa-siswi dapat menanamkan kerja sama sekaligus mampu bekerja mandiri. Hal ini juga sejalan dengan berbagai tuntutan saat ini di mana siswa-siswi harus memiliki wawasan tanpa mengesampingkan kemampuan berpikir dan sikap, sehingga tidak hanya terpusat ke pelajaran teoretis. Karena bersifat tambahan dari pendidikan formal, maka kegiatan ekstrakurikuler diselenggarakan di luar jam pelajaran sekolah. Pemilihan subjek ekstrakurikuler seharusnya mampu mengakomodasi potensi dan minat siswa-siswi yang belum tersalurkan di sekolah. Pelajaran elektronika sudah mulai banyak dijumpai tidak hanya di perguruan tinggi tapi juga ke bangku sekolah. Selain itu banyak juga lembaga pelatihan dan kursus yang menyediakan pelajaran serupa. Akan tetapi kegiatan ekstrakurikuler ekstrakurikuler elektronika masih dikategorikan sebagai kegiatan yang mahal untuk dilaksanakan secara rutin karena membutuhkan dana yang cukup besar untuk pelaksanaannya jika meliputi tidak hanya teori tetapi juga praktiknya. Oleh karena itu masih banyak sekolah-sekolah yang belum bisa atau pun belum mampu mengadakan kegiatan ekstrakurikuler elektronika karena masalah tersebut (Widiastuti, dkk., 2016; Saputra, 2016 [4]).

SD FX. Marsudirini 78 Salatiga adalah salah satu sekolah yang ada di Salatiga yang berkeinginan untuk menginisiasi kegiatan ekstrakurikuler elektronika, meski beberapa kegiatan ekstrakurikuler juga dilaksanakan di sekolah ini. Untuk memulai ekstrakurikuler elektronika, SD FX. Marsudirini 78 Salatiga mengalami beberapa kesulitan terkait materi ajar, sarana pembelajaran, maupun tenaga pengajarnya. Untuk itulah kegiatan pengabdian masyarakat ini dilakukan untuk menginisiasi sekaligus menguatkan ekstrakurikuler elektronika, dengan maksud pihak sekolah dapat melaksanakannya secara mandiri (Daryanto, 2013 [2] ). Dengan adanya kegiatan ekstrakurikuler elektronika ini, diharapkan siswa-siswi siap dengan kemajuan perkembangan teknologi yang sangat pesat dan ke depannya dapat menguasainya, sehingga dapat berguna bagi kehidupannya dan banyak orang (Yolanda, 2018; Wijaya, 2013 [6]).

\section{Target dan Luaran}

Target yang diharapkan melalui kegiatan pengabdian masyarakat ini adalah siswa mampu mempelajari, mengerti serta bisa merangkai atau mempraktikkan dengan materi yang telah diberikan, yaitu antara lain :

- Rangkaian display LED sederhana

- Rangkaian lampu otomatis

- Rangkaian flip flop

- Rangkaian counter 7 segment

- Rangkaian sirine bel pintu

- Rangkaian lampu lalulintas

- Rangkaian bel sepeda

- Rangkaian adjustable blinking LED

- Rangkaian pendeteksi air

- Rangkaian running LED

Adapun proses penyampaian materi kepada siswa sudah disetarakan dengan kemampuan anak sekolah dasar kelas 3, 4, 5, dan 6.

Jenis luaran yang dihasilkan adalah berupa modul pembelajaran elektronika dari rangkaianrangkaian di atas yang mencakup informasi tentang alat dan bahan, cara merangkai, cara kerja rangkaian dan juga indikator keberhasilan dari rangkaian yang dapat dimengerti serta dipahami oleh siswa SD F.X. Marsudiri 78 Salatiga maupun gurunya.

\section{Metodologi}

Untuk setiap materi rangkaian, metode pelaksanaan yang diberikan mengikuti diagram alir berikut ini: 


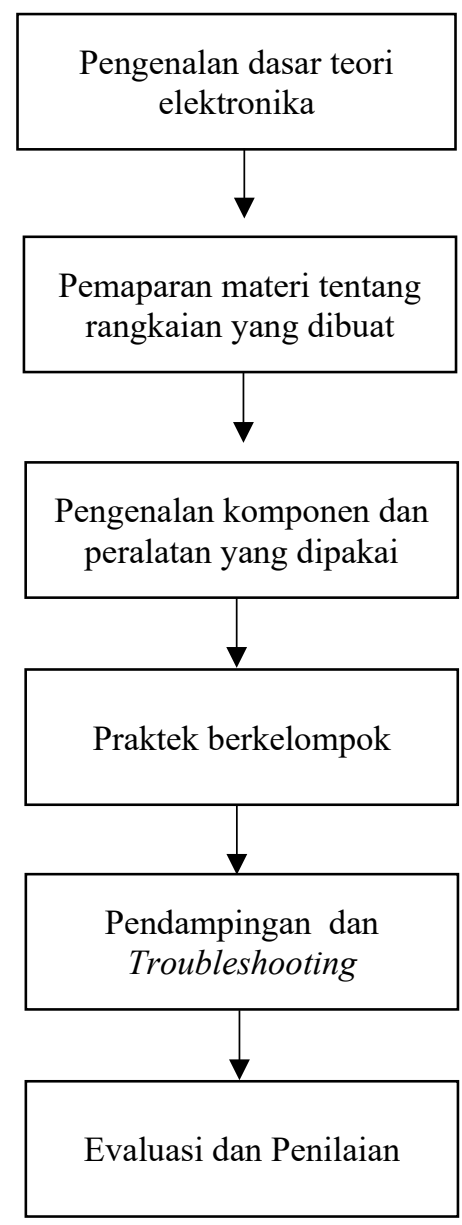

Gambar 1. Metode pelaksanaan

Dalam pemberian materi siswa diharapkan mempunyai gambaran tentang materi apa yang nanti akan dipraktikkan, setelah itu siswa diberi waktu untuk mencoba merangkai. Jika dalam proses tersebut siswa menemui kesulitan maka akan dibantu oleh pembimbing. Kemudian jika tidak ada kesulitan yang dialami siswa maka siswa dibiarkan mandiri untuk merangkai sampai menghasilkan wujud rangkaian yang diinginkan.

Materi pembelajaran yang diberikan merupakan materi-materi dasar yang tingkat kesulitannya mudah dimengerti oleh anak-anak jenjang sekolah dasar dalam hal ini siswa diharapkan bisa menyelesaikan permasalahan yang ditemui saat proses belajar mengajar berlangsung. Berdasarkan Gambar 1 di atas, siswa diberikan gambaran materi yang akan dipraktikkan, kemudian dilanjutkan minggu berikutnya dengan pembagian komponen. Para siswa diharapkan mengerti tiap-tiap komponen serta peralatan yang diperlukan. Setelah itu baru kemudian siswa-siswi mulai merangkai. Dalam perangkaian siswa diberikan panduan pengerjaan berupa skematik rangkaian di atas breadboard yang dibuat dengan software fritzing. Jika di dalam perangkaian siswa menemui kesulitan maka pembimbing akan membantu mengoreksi kesalahan yang dihadapi siswa dengan cara mengarahkan siswa. Di sini arahan pembimbing hanya bersifat instruksional dan tidak ikut membantu mengerjakan. Jika siswa tidak menemui kesulitan dalam perancangan dan rangkaian sudah sesuai yang diinginkan maka hasil perangkaian akan dinilai oleh pembimbing.

Berikut ini adalah contoh-contoh rangkaian yang dikerjakan oleh para siswa (Bishop, 2002 [1]) :

\subsection{Rangkaian display LED sederhana}

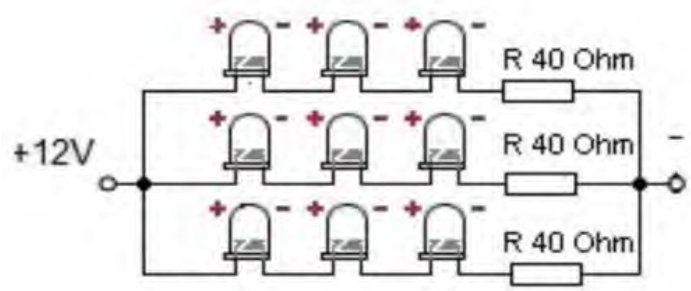

Gambar 2. Skematik rangkaian display LED sederhana

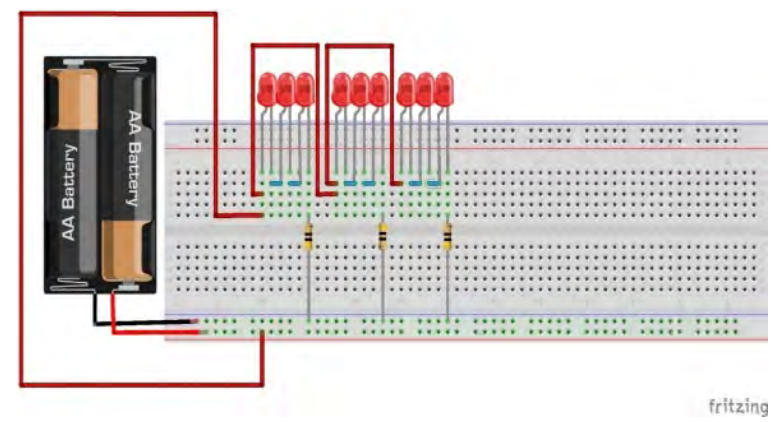

Gambar 3. Panduan display LED sederhana

3.2. Rangkaian lampu otomatis

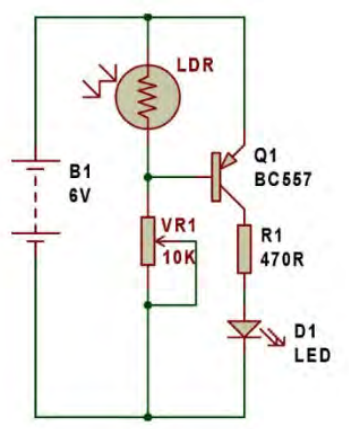

Gambar 4. Skematik rangkaian lampu otomatis 


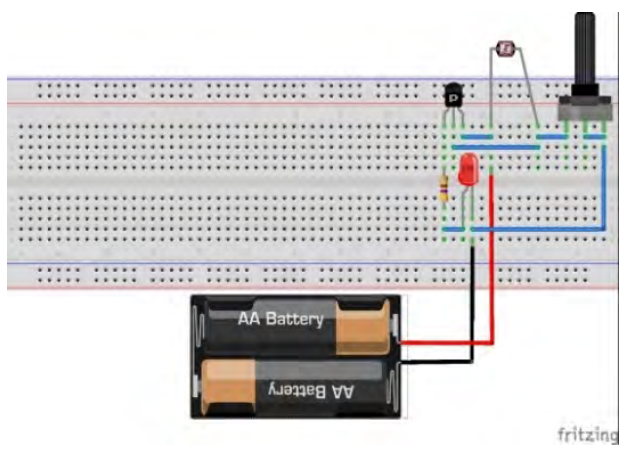

Gambar 5. Panduan rangkaian lampu otomatis

3.3. Rangkaian flip-flop

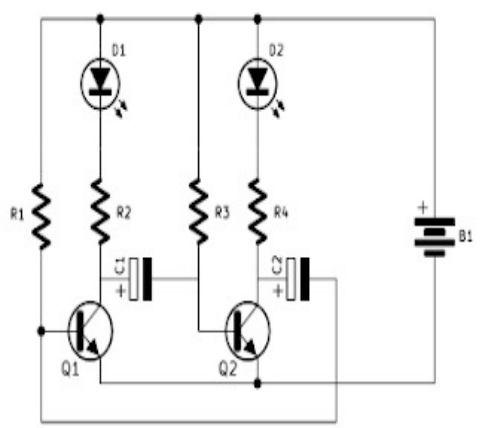

Gambar 6. Skematik rangkaian flip-flop

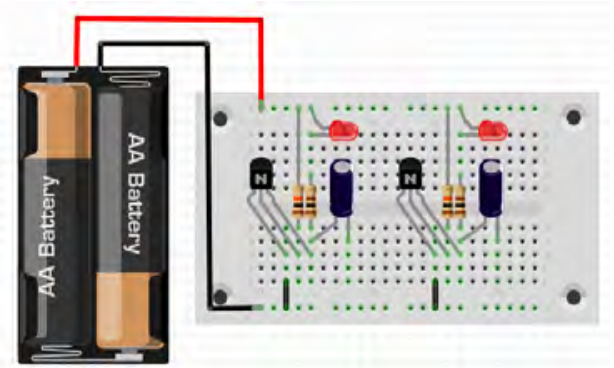

Gambar 7. Panduan rangkaian flip-flop

3.4. Rangkaian counter 7 segments

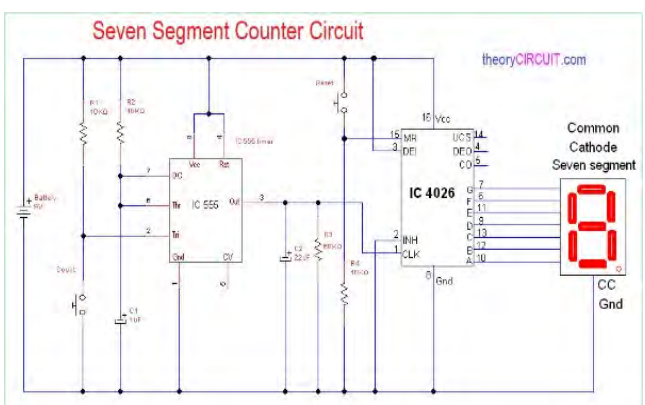

Gambar 8. Skematik rangkaian counter 7 segments

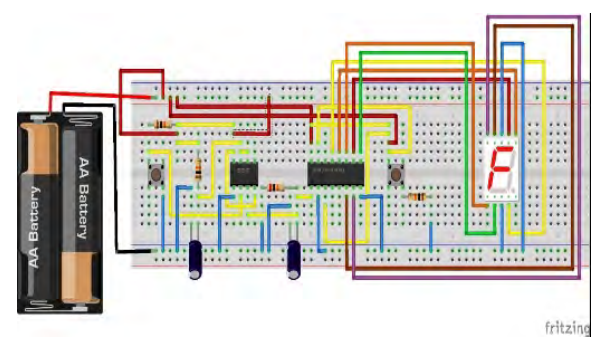

Gambar 9. Panduan rangkaian counter 7 segments

3.5. Rangkaian bel pintu sederhana

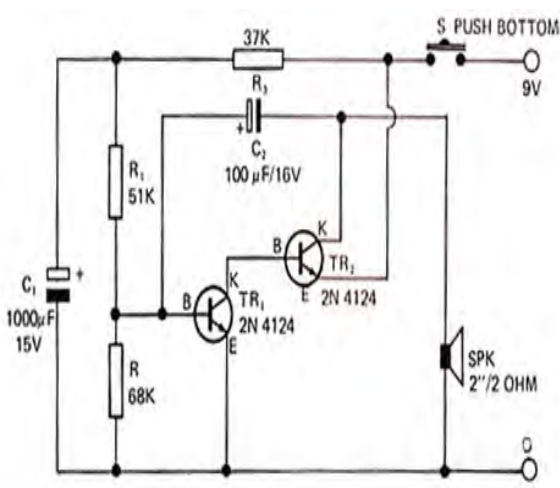

Gambar 10. Skematik rangkaian bel pintu sederhana

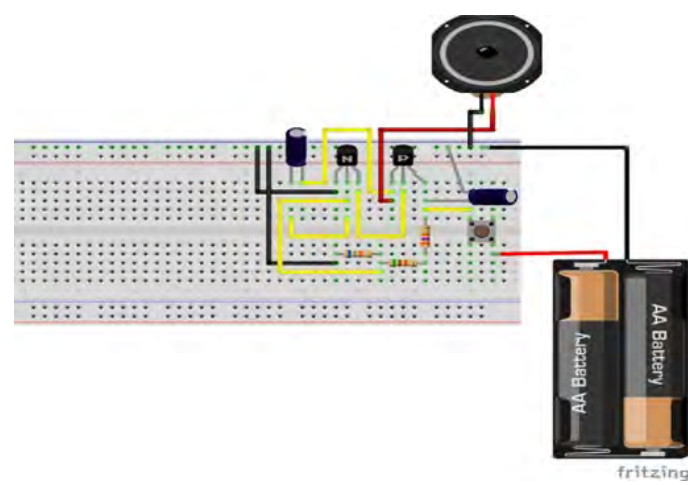

Gambar 11. Panduan rangkaian bel pintu sederhana

3.6. Rangkaian lampu lalu lintas

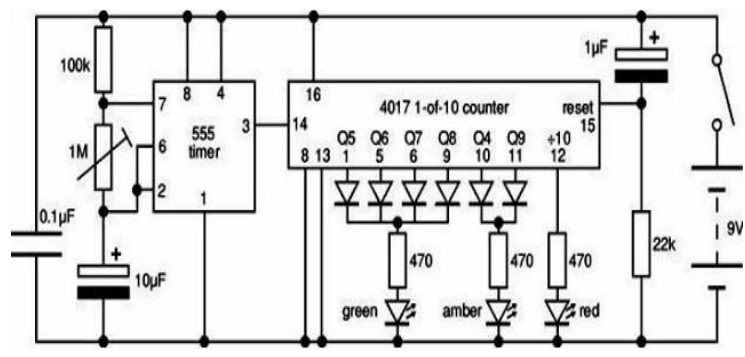

Gambar 12. Skematik rangkaian lampu lalu lintas 


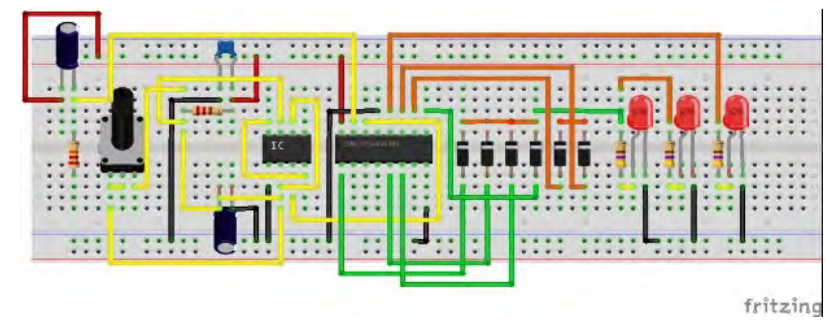

Gambar 13. Panduan rangkaian lampu lalu lintas

3.7. Rangkaian bel sepeda sederhana

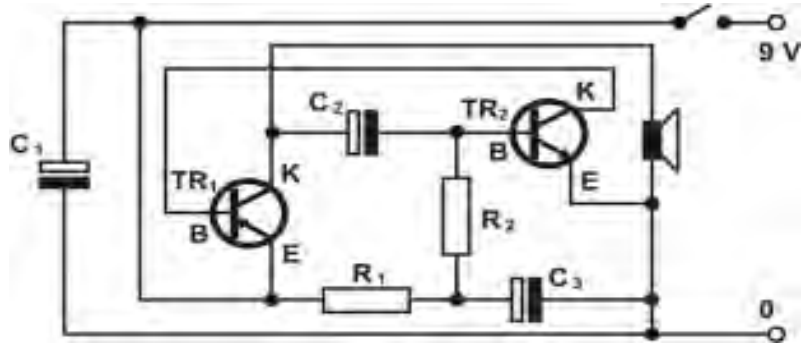

Gambar 14. Skematik rangkaian bel sepeda sederhana

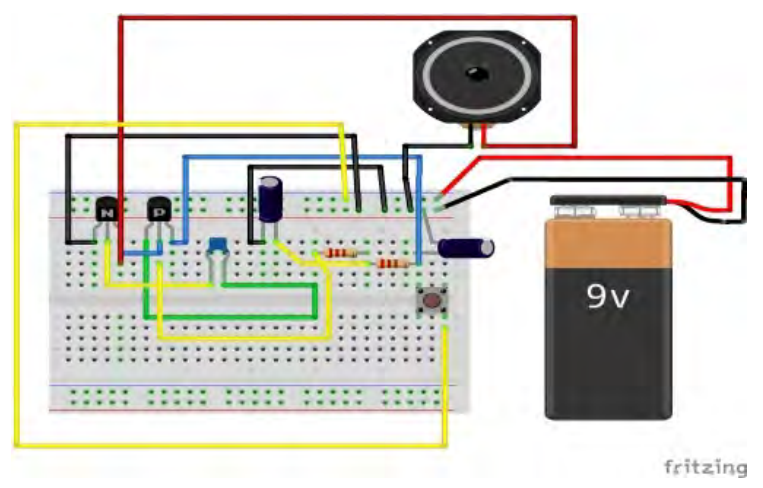

Gambar 15. Panduan rangkaian bel sepeda sederhana

3.8. Rangkaian Adjustable blinking LED

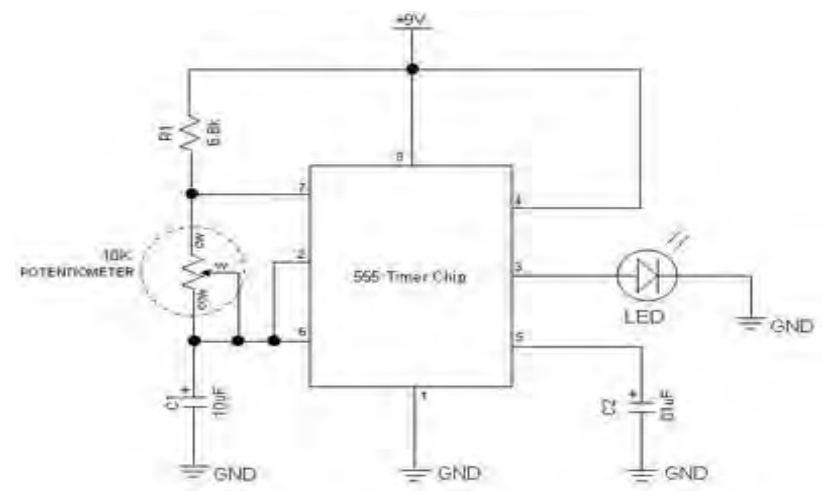

Gambar 16. Skematik rangkaian adjustable blinking LED

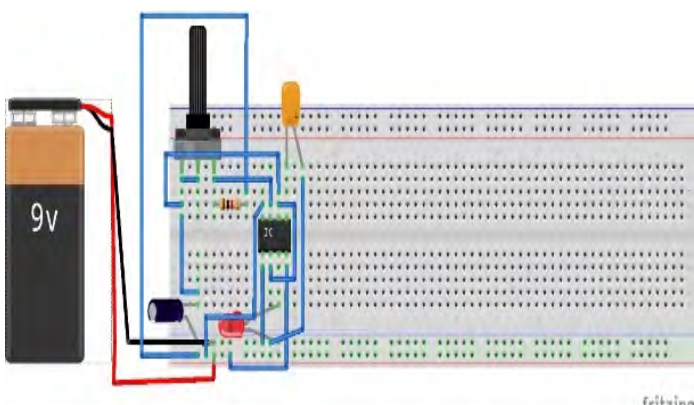

Gambar 17. Panduan Rangkaian adjustable blinking LED

3.9. Rangkaian pendeteksi air

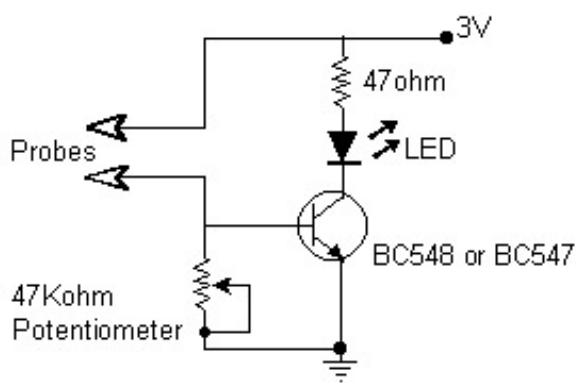

Gambar 18. Skematik rangkaian pendeteksi air

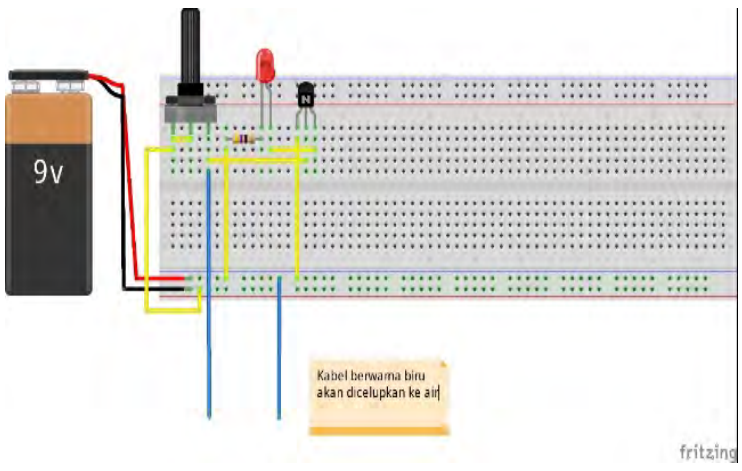

Gambar 19. Panduan rangkaian pendeteksi air

3.10. Rangkaian running LED

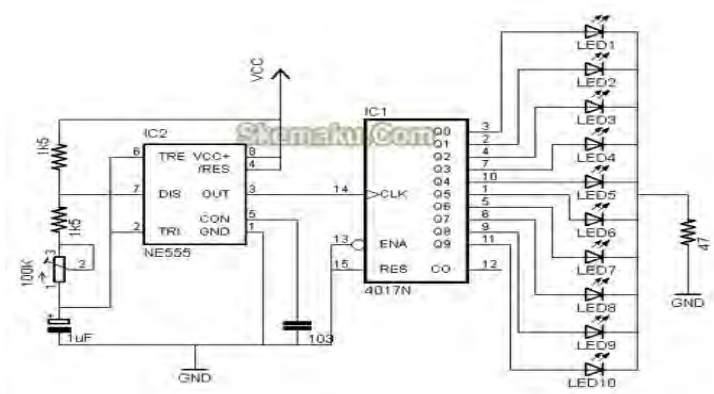

Gambar 20. Skematik rangkaian running LED 


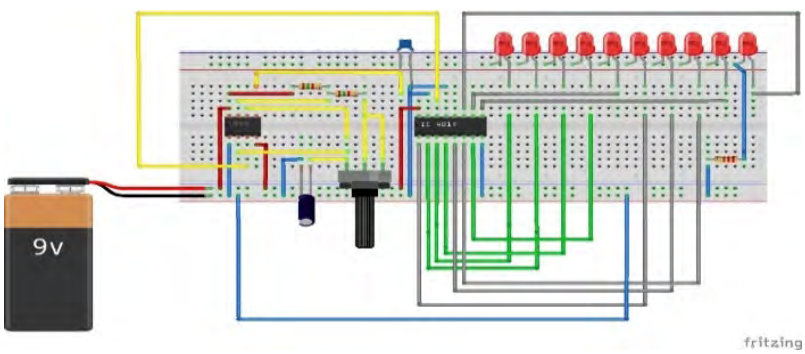

Gambar 21. Panduan rangkaian running LED

\section{Pembahasan}

Kegiatan ekstrakurikuler elektronika di SD FX. Marsudirini 78 Salatiga dilangsungkan setiap hari Rabu dan Sabtu di setiap minggunya. Hari Rabu digunakan untuk kelas 5 dan Sabtu untuk kelas 3, 4 dan 6 yang berlangsung di dalam ruang kelas masing-masing. Durasi ekstrakurikuler berlangsung satu jam untuk setiap kelas. Suasana ekstrakurikuler dapat dilihat pada Gambar 22, 23, dan 24. Kegiatan ini mendapat tanggapan yang sangat baik dari siswasiswi, ini dilihat dari waktu penyelesaian sebuah rangkaian yang diberikan kepada siswa, rata-rata kelompok dapat menyelesaikan tiap-tiap rangkaian dalam waktu kurang dari satu jam. Apabila di dalam kelompok menyelesaikan sebuah rangkaian kurang dari satu jam maka proses perangkaian akan dilakukan ulang dari awal oleh siswa yang belum mendapat porsi dalam merangkai atau kekurangan porsi merangkai. Hal ini sangat merepresentasikan bahwa materi yang diberikan kepada siswa mudah dicerna dan dapat diterima dengan baik.

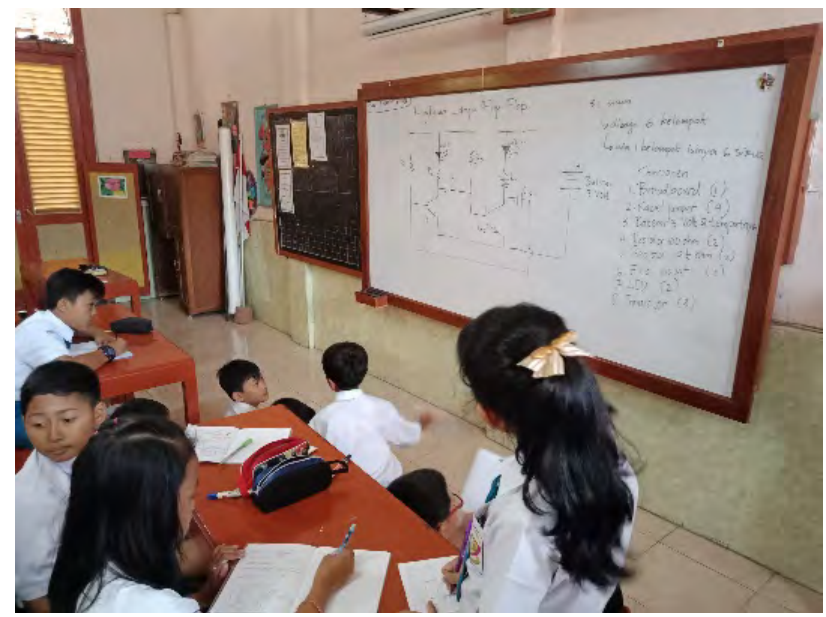

Gambar 22. Suasana penjelasan teoretis rangkaian

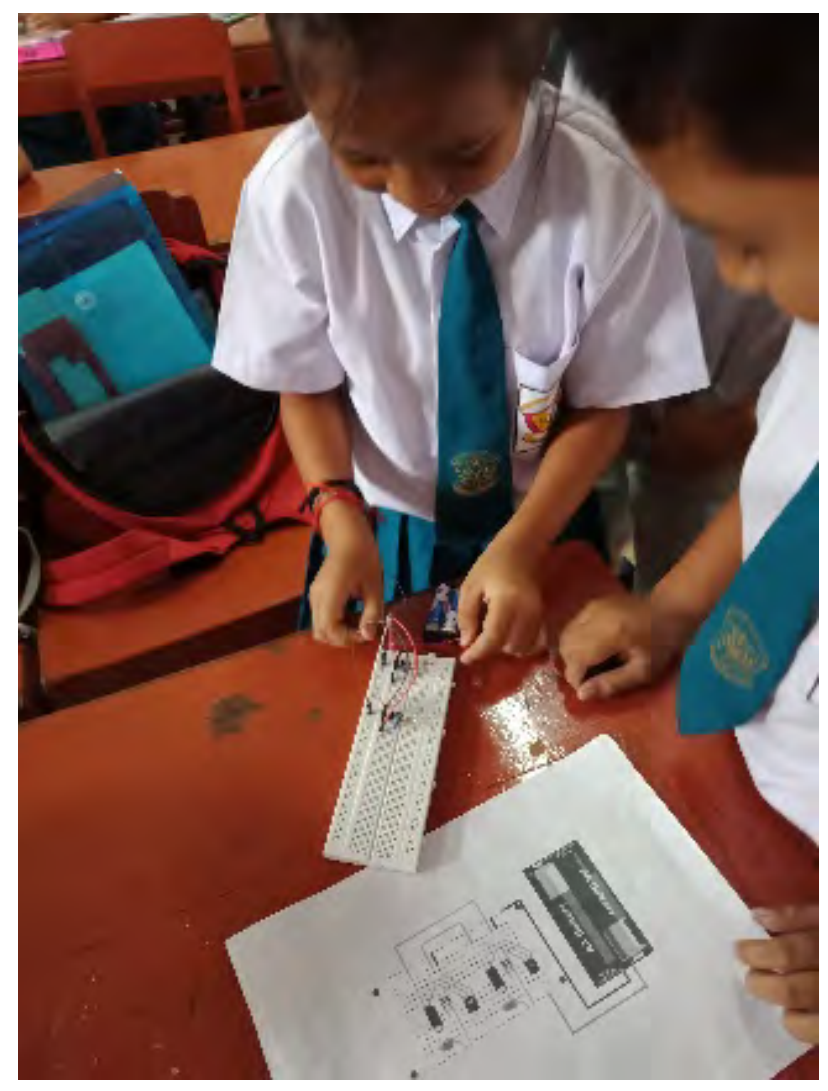

Gambar 23. Siswa mencoba merangkai berdasarkan panduan

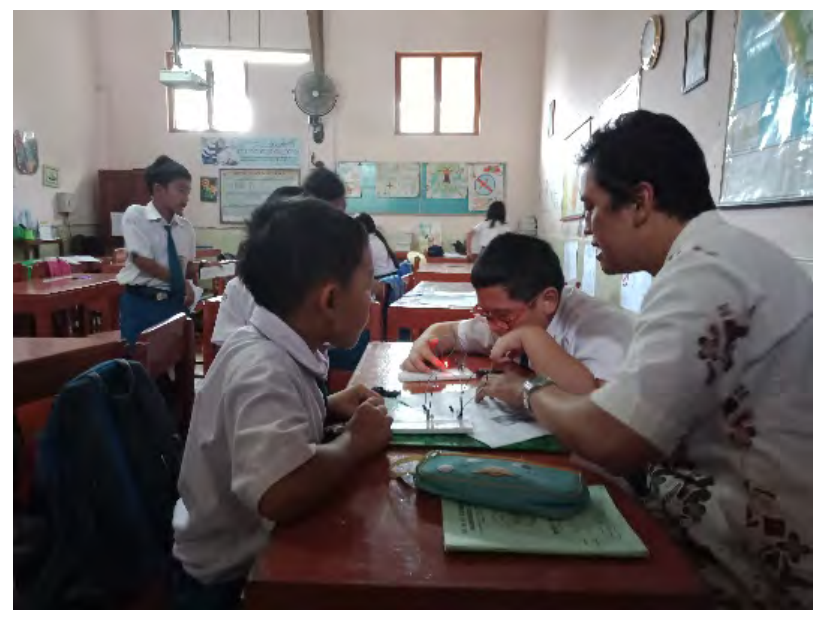

Gambar 24. Pendampingan dan troubleshooting

Kegiatan ini mempunyai manfaat yang sangat yang sangat baik untuk siswa-siswa sendiri yaitu mengasah kemampuan berpikir, melatih kreativitas dalam memecahkan sebuah permasalahan. Di dalam kegiatan ekstrakurikuler, rata-rata siswa antusias dan terpacu dalam mengikuti kegiatan ini. Namun terdapat pula beberapa siswa tidak langsung 
dapat memahami materi dan mengaplikasikan materi itu sendiri. Oleh karenanya, siswa-siswi tersebut harus diberikan perhatian lebih atau dengan kata lain harus didampingi dan diarahkan dalam proses perangkaian

\section{Kesimpulan}

Kegiatan ekstrakurikuler elektronika bertujuan untuk mengembangkan potensi siswa dalam dunia elektronika dan juga dapat mengembangkan atau mengasah kreativitas siswa dalam berpikir serta mempersiapkan siswa dalam menghadapi perkembangan teknologi di era modern ini. Di dalam kegiatan ekstrakurikuler elektronika di SD FX. Marsudirini 78, Salatiga siswa sudah menguasai materi dan bisa merangkai serta rangkaian yang dihasilkan sesuai dengan yang diinginkan pembimbing. Hal ini terbukti dari siswa atau kelompok yang mampu menyelesaikan sebuah rangkaian yang diberikan oleh pembimbing sebelum durasi waktu yang ditentukan.

Saran yang dapat diberikan untuk kegiatan ini adalah pembimbing harus lebih bisa dalam menguasai kelas agar materi yang disampaikan untuk para siswa bisa dicerna dengan baik sehingga para siswa tidak kesulitan dalam proses perangkaian.

\section{Ucapan Terima Kasih}

Kegiatan pengabdian masyarakat ini didukung oleh Universitas Kristen Satya Wacana dalam hal pendanaan

\section{Daftar Pustaka}

[1] Bishop, O., 2002. Dasar-Dasar Elektronika. Penerbit Erlangga.

[2] Daryanto, 2013. Menyusun Modul Bahan Ajar Untuk Persiapan Guru Dalam Mengajar. Yogyakarta: Gava Media.

[3] Wijaya, H.A., 2013. Evaluasi Implementasi Pelatihan Robotika Menggunakan Arduino di SMK Negeri 1 Sedayu Bantul. Universitas Negeri Yogyakarta.

[4] Widiastuti I., Arifin S., dan Widiawan, B., 2016. Peningkatan Kreativitas Siswa SD Negri Karangrejo 2 melalui Ekstrakurikuler Robotika. Seminar Hasil Penelitian dan Pengabdian Masyarakat Dana BOPTN Tahun 2016, Jember

[5] Saputra, L.K.P., Lukito, Y., 2016. Pelatihan Pengantar Robotika Berbasis Lego NXT Sebagai Kegiatan Ekstrakurikuler Siswa SMA. Seminar
Nasional Pengabdian kepada Masyarakat, Yogyakarta.

[6] Yolanda, Y., Arini, W., 2018. Pelatihan Robotik Line Follower Dan Teknologi Arduino Bagi Guru MIPA Dan Pelajar SMA/SMK Di Wilayah Kabupaten Musi Rawas. Jurnal Cemerlang: Pengabdian Pada Masyarakat, 1 (1), pp. $1-11$. 